\title{
THE DESIGN ARGUMENT SALVAGED? ASSESSING THE CONTEMPORARY ARGUMENT FROM IMPROBABILITY
}

\begin{abstract}
Some features within the physical universe appear to be so well-ordered that they have been regarded as evidence of the existence of a supernatural being who has designed them. This history of the so-called design argument is millennia-long, and various formulations of the argument have been presented. In this paper, I explore one contemporary version of the design argument proposed by the Intelligent Design movement, and analyze its advantages and disadvantages in comparison to one of the most famous classical versions of the argument.
\end{abstract}

Keywords: design argument; natural theology; Intelligent Design

1. Introduction. 2. The intuition of a design: the analogical design argument. 3. Hume's critique against the analogical argument. 4. The persistence of the design intuition and the need for evidence. 5. Intelligent Design and the New Design Argument. 6. Detecting design through specified complexity. 7. From design to a designer. 8. Problems with the ID's design argument.

9. Conclusion.

\section{INTRODUCTION}

The intuition that some features within the physical universe are so well-ordered or so appropriately serving some complex function that they must have been designed for a purpose has been one of the strongest reasons to believe that the world is governed by a supernatural being, such as the Christian God. The history of the so-called design argument reaches back to antiquity. ${ }^{1}$ The argument was most famously promoted by British natural theologians in the 17th-19th

1 D. Sedley, Creationism and Its Critics in Antiquity (Sather Classical Lectures 66), University of California Press, Berkeley - Los Angeles 2007. 
centuries, when it was argued that the best explanation for the appearance of complex biological organisms was that they had been purposefully designed by God. Although biology has since shown that this complexity can be explained by the gradual development of organisms, the intuitive attractiveness of design has not disappeared. During the last twenty years, a new movement promoting the idea that it is actually possible to gain reliable empirical evidence pointing to a design in nature has emerged: the so-called Intelligent Design movement. In this paper, I review the movement's design argument and compare its advantages and disadvantages to the classical argument of British natural theologians in the light of the criticism presented against the original argument by David Hume.

\section{THE INTUITION OF A DESIGN: THE ANALOGICAL DESIGN ARGUMENT}

The design argument gained wide popularity in the heyday of British natural theology in the 17th through 19th centuries. Scientists (or, rather, natural philosophers or natural theologians) like John Ray ${ }^{2}$ and William Derham $^{3}$ claimed that many features of nature clearly point to an extremely powerful designer of such features, and as Derham put it, prove the "unreasonableness of infidelity". ${ }^{4}$ British natural theologians were not the only ones concerned with natural theology. For the purposes of this paper, however, focusing on them narrows the scope appropriately so that the topic becomes manageable, at least to some extent.

In his renowned treatise Natural Theology, ${ }^{5}$ William Paley described the intuition behind the design argument by drawing an analogy

2 J. Ray, The Wisdom of God Manifested in the Works of Creation, R. Harbin, London 1717.

3 W. Derham, Physico-theology, or a Demonstration of the Being and Attributes of God from His Works of Creation, W. Innys and J. Richardson, London 1754.

4 Ibid., 428 (Book XI, Chapter III).

5 W. Paley, Natural Theology, or Evidence of the Existence and Attributes of the Deity, Collected from the Appearances of Nature, eds. M.D. Eddy, D. Knight, Oxford University Press, Oxford 2006. 
between the design of human-made artifacts, such as a pocket watch, and the apparent design observed in the natural world. Paley illustrated the design intuition as follows, offering first an everyday example of what qualifies as a having a design: "In crossing a heath, suppose I pitched my foot against a stone, and were asked how the stone came to be there; I might possibly answer, that, for anything I knew to the contrary, it had lain there forever. ... But suppose I had found a watch upon the ground, and it should be inquired how the watch happened to be in that place; I should hardly think of the answer I had before given. ... [t] he inference, we think, is inevitable; that the watch must have had a maker; that there must have existed, at some time, and at some place or other, an artificer or artificers, who formed it for the purpose which we find it actually to answer; who comprehended its construction, and designed its use." ${ }^{6}$

Paley then drew an analogy between the design of the watch and the apparent design observed in the natural world: "[E]very indication of contrivance, every manifestation of design, which existed in the watch, exists in the works of nature; with the difference, on the side of nature, of being greater or more, and that in a degree which exceeds all computation. I mean that the contrivances of nature surpass the contrivances of art, in the complexity, subtility, and curiosity of the mechanism; and still more, if possible, do they go beyond them in number and variety." 7

For Paley, it was self-evident that the existence of such a complex and perfectly functioning artefact as a watch would imply the existence of a designer who made it. Since many natural objects were, in Paley's view, clearly more complex and more skillfully constructed than a watch, he concluded that it could indisputably be inferred that a supernatural designer of the natural objects exists: "The marks of design are too strong to be gotten over. Design [in nature] must have

6 Ibid., 7-8.

7 Ibid., 16. 


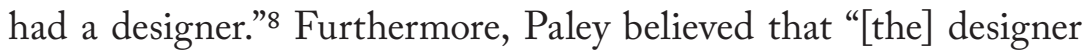
must have been a person. That person is God."

\section{HUME'S CRITIQUE AGAINST THE ANALOGICAL ARGUMENT}

In his Dialogues Concerning Natural Religion, David Hume famously pointed out that the traditional argument from analogy suffers from several vulnerabilities. First, according to Hume, the argument fails because it assumes too complete a resemblance between two different sets of objects. Indeed, the analogical argument is based on the thought that the more properties two objects are known to share, the more likely it is that they also share other properties. Hume points out, however, that this line of thinking only carries so far: "That a stone will fall, that fire will burn, that the earth has solidity, we have observed a thousand and a thousand times; and when any new instance of this nature is presented, we draw without hesitation the accustomed inference. The exact similarity of the cases gives us a perfect assurance of a similar event; and a stronger evidence is never desired nor sought after. But where-ever you depart, in the least, from the similarity of the cases, you diminish proportionably the evidence; and may at last bring it to a very weak analogy, which is confessedly liable to error and uncertainty." 10

Thus, the similarities between two different kinds of things, for example between human-made objects (such as a pocket watch) and natural objects (such as biological structures), are still always incomplete. Different things, as similar as they might seem at first glance - or even after closer inspection - may share many properties but never all of them. Consequently, it is impossible to know whether

8 Ibid., 229.

9 Ibid.

10 D. Hume, Dialogues Concerning Natural Religion, Penguin Books, London 1779, D 2.7, KS 144. 
they share the property of "being designed." In other words, inferring a particular object as designed is more or less based on an individual observer's subjective intuition, rather than objective evidence.

Second, the analogical argument cannot show that the designer would be some particular being, for instance, the God of Christianity, as has often been assumed in the Western tradition. In fact, Hume claims that the argument does not even offer grounds for assuming that there would exist just one designer. ${ }^{11}$ Logically, there are no grounds for ruling out the possibility of multiple designers. ${ }^{12}$ "And what shadow of an argument... can you produce, from your hypothesis, to prove the unity of the Deity? A great number of men join in building a house or ship, in rearing a city, in framing a commonwealth: why may not several deities combine in contriving and framing a world? This is only so much greater similarity to human affairs. By sharing the work among several, we may so much farther limit the attributes of each, and get rid of that extensive power and knowledge, which must be supposed in one deity, and which, according to you, can only serve to weaken the proof of his existence." 13

Third, the argument from analogy also calls the assumptions about the perfectness and infinity of the designer into question, making it even more difficult to associate the designer with the Christian God: "This world, for aught he knows, is very faulty and imperfect, compared to a superior standard; and was only the first rude essay of some infant deity, who afterwards abandoned it, ashamed of his lame performance: it is the work only of some dependent, inferior deity; and is the object of derision to his superiors: it is the production of old age and dotage in some superannuated deity; and ever since his

11 Ibid., Pt. V.

12 Similarly, Immanuel Kant argued that the design argument can at most prove the existence of some kind of architect, not the God of Christianity or a similar "all-sufficient original being" (I. Kant, The Critique of Pure Reason, trans. from German and eds. P. Guyer, A.W. Wood, Cambridge University Press, Cambridge 1988).

13 D. Hume. Dialogues Concerning Natural Religion, op. cit., D 5.8, KS 167-8. 
death, has run on at adventures, from the first impulse and active force, which it received from him." ${ }^{14}$

\section{THE PERSISTENCE OF THE DESIGN INTUITION AND THE NEED FOR EVIDENCE}

Despite philosophical criticism, until the competing evolutionary explanation was introduced by Charles Darwin ${ }^{15}$ and Alfred Russel Wallace ${ }^{16}$ in the mid-nineteenth century, the design argument was widely endorsed. Both philosophers and scientists were convinced that the most reasonable explanation for the perceived adaptedness of organisms was that they had been purposefully designed by God. ${ }^{17}$ Although evolutionary biology has since shown that the complexity of life forms can be explained by the gradual development of organisms, the intuitive attractiveness of a design has not disappeared. Even as prominent an atheist as Richard Dawkins admits that many features of the natural world look as if they have been designed. According to him, "[b]iology is the study of complicated things that give the appearance of having been designed for a purpose." 18 However, Dawkins hastens to add that there is a clear distinction between complicated biological objects, which appear to be designed,

14 Ibid., D 5.12, KS 168-9.

15 C. Darwin, On the Origin of Species by Means of Natural Selection, or the Preservation of Favoured Races in the Struggle for Life, John Murray, London 1859.

16 A.R. Wallace, On the Tendency of Varieties to Depart Indefinitely From the Original Type, in: Alfred Russel Wallace Classic Writings, Paper 1, ed. C.H. Smith, Western Kentucky University 2009.

17 E. Sober, Philosophy of Biology, Westview, Boulder 1993, 29. For a thorough presentation of the historical development and contemporary perspectives on the relationship between the design argument and the theory of evolution, see A.E. McGrath, Darwinism and the Divine - Evolutionary Thought and Natural Theology, Wiley-Blackwell, Oxford 2011.

18 R. Dawkins, The Blind Watchmaker - Why the Evidence of Evolution Reveals a Universe without Design (Illustrated Edition), W.W. Norton, New York 2015, 4. 
and man-made artefacts, which "are complicated and obviously designed for a purpose." 19

It is true that the appearance of a design does not necessarily coincide with an actual design. In other words, the mere intuition that some particular object - as complex as it may appear to be - is designed does not mean that it really is. Further evidence that reaches beyond intuition is needed. It has been argued that humans might have developed a tendency towards intuitively favouring teleological explanations as the cause of ambiguous phenomena because it would have given us a survival advantage in avoiding predators. ${ }^{20}$ Justin Barret explains that our "agent detection device suffers from hyperactivity, making it prone to find agents around us, including supernatural ones, given fairly modest evidence of their presence". ${ }^{21}$ However, the existence of a hyperactive agent detection device in itself neither proves nor disproves the existence of supernatural agents. ${ }^{22}$ To repeat, we need further evidence.

During the last twenty years, a new movement promoting the idea that it might be possible to gain reliable empirical evidence of a design in nature has emerged: Intelligent Design (ID). ID can be defined as follows: "Intelligent design (ID) is a scientific theory that employs the methods commonly used by other historical sciences to conclude that certain features of the universe and of living things

19 Ibid., 4.

20 J. Barrett, Exploring the Natural Foundations of Religion, Trends in Cognitive Sciences 4(2000)1, 29-34.

21 Ibid., Why Would Anyone Believe in God?, AltaMira, Walnut Creek 2004, 31.

22 D. Leech, A. Visala, The Cognitive Science of Religion - A Modified Theist Response, Religious Studies 47(2011)3, 301-316; Ibid., The Cognitive Science of Religion - Implications for Theism?, Zygon: Journal of Religion and Science 46(2011)1, 47-64; A. Visala, Naturalism, Theism and the Cognitive Study of Religion - Religion Explained? (Ashgate Science and Religion Series), Ashgate, Farnham 2011. 
are best explained by an intelligent cause, not an undirected process such as natural selection."23

According to one of its major proponents, William A. Dembski, whose formulation of the design argument I consider in this paper, ID "is linked both conceptually and historically" to British natural theology, which he describes as "the attempt... to understand divine action scientifically." 24 Although sometimes regarded as outdated, for Dembski natural theology contains a seed of truth which could be developed further: "British natural theology died in the nineteenth century. A positivist conception of science that restricted science to the study of undirected natural causes effectively did away with it. That faulty conception of science is still with us. ... Although natural theology was not without its problems, it contained a core idea-design-which neither positivism nor Darwinism ever adequately addressed. ... [T] he blanket dismissal of natural theology in the nineteenth century was not warranted and... its core idea of design remains viable." 25

\section{INTELLIGENT DESIGN AND THE NEW DESIGN ARGUMENT}

The strategy Dembski and his fellow advocates of ID employ in formulating the design argument is substantially different from that of the natural theologians in the preceding centuries. Whereas Paley and his contemporaries mostly relied on analogical arguments, the new versions of the argument draw on logic and probability. In this paper the focus is on Dembski's variant, which can be regarded as the most rigorous formulation of the design argument among ID

23 The Center for Science and Culture, What Is the Science Behind Intelligent Design?, 2009 (https://www.discovery.org/a/9761/), [accessed 09/2020].

24 W.A. Dembski, Intelligent Design - The Bridge Between Science and Theology, InterVarsity, Downers Grove 1999, 16.

25 Ibid., 16. 
proponents. ${ }^{26}$ The argument is eliminative: a design is inferred if competing explanations can be ruled out with a high probability. Dembski holds that there are three possible modes of explanation of any event occurring in the universe: regularity, chance, and design. ${ }^{27}$ These three explanatory modes are mutually exclusive and exhaustive, in other words, one and only one of them is the cause of any particular event. ${ }^{28}$

According to ID, in biology the argument can be used to show that there are some biological structures that would not have developed through undirected natural causes, contrary to what is assumed in the theory of evolution. Dembski stresses that although a design can be detected in any kind of phenomena (abstract or material, real of theoretical), cases of a design observed in the biological world are particularly significant. Supporters of ID claim that it can be empirically shown that some biological structures are too complex to have emerged through chance and regularity alone, that is, through natural causes. Consequently, because the only option for natural causes is a supernatural design, it is possible to argue for the existence of God (or some other supernatural being) convincingly.

Supposedly, the probabilistic design argument might be able to escape much of Hume's criticism against Paley's argument, although the basic idea of inferring the existence of God from features of nature is similar. This is because the new version of the argument

26 Ibid., The Design Inference - Eliminating Chance through Small Possibilities (Cambridge Studies in Probability, Induction, and Decision Theory), Cambridge University Press, Cambridge 1998; Ibid., Intelligent Design - The Bridge Between Science and Theology, op. cit.; Ibid., No Free Lunch - Why Specified Complexity Cannot Be Purchased without Intelligence, Rowman and Littlefield, Plymouth 2002. For other versions of the argument, see, e.g.: M.J. Behe, The Edge of Evolution - The Search for the Limits of Darwinism, Free Press, New York 2007; S.C. Meyer, Signature in the Cell - DNA and the Evidence for Intelligent Design, Harper One, New York 2009.

27 In his later writings, Dembski uses "necessity" instead of "regularity".

28 W.A. Dembski, The Design Inference - Eliminating Chance through Small Possibilities, op. cit., 36-39. 
does not rely solely on intuition, that is, an object does not count as designed simply because it intuitively appears to have a design. Instead, ID tests the design intuition with formal calculations to find out whether it actually is more probable that the emergence of the object is due to a design than to other causes. Dembski holds that the progress of science has now led to the point where we can reliably say what natural causes are and are not capable of producing: "It is the empirical detectability of intelligent causes that renders intelligent design a fully scientific theory and distinguishes it from the design arguments of philosophers or what has traditionally been called ,natural theology.' ... Precisely because of what we know about undirected natural causes and their limitations, science is now in a position to demonstrate design rigorously. In the past design was a plausible but underdeveloped philosophical intuition. Now it is a robust program of scientific research." 29

\section{DETECTING DESIGN THROUGH SPECIFIED COMPLEXITY}

Dembski claims that it is possible to determine whether an object is caused by chance, regularity, or design by examining, first, the probability of the object coming into existence and, second, whether the object is "specified" or not. ${ }^{30}$ According to him, after observing some interesting event, it should first be evaluated whether the probability of the event occurring is high, that is, one. ${ }^{31}$ If this is the case, the event is attributed to regularity. If the probability is not high, it is next evaluated whether the probability is intermediate (higher than $10^{-150) .32}$ If the event is of intermediate probability, it is attributed

29 Ibid., Intelligent Design - The Bridge Between Science and Theology, op. cit., 107.

30 Ibid., The Design Inference - Eliminating Chance through Small Possibilities, op. cit., 36-49.

31 Dembski uses the terms "object" and "event" somewhat interchangeably. In his theory, an event occurring and an object coming into existence are essentially the same thing.

32 see below for details. 
to chance. Only with probabilities lower than this, the possibility of design needs to be considered: "Regularities are always the first line of defense. If we can explain by means of regularity, chance and design are automatically precluded. Similarly, chance is always the second line of defense. If we can't explain by means of a regularity, but can explain by means of chance, then design is automatically precluded. ... [E]xplanations that appeal to regularity are indeed simplest, for they admit no contingency, claiming things always happen that way. Explanations that appeal to chance add a level of complication, for they admit contingency, but one characterized by probability. Most complicated are those explanations that appeal to design, for they admit contingency, but not one characterized by probability." 33

If the probability of the event turns out to be small (lower than $10^{-150}$ ), the event is - in the ID terminology - "complex" and the possibility of a design should be examined. The important thing now is to find out whether the event is "specified" or not. If the event is specified, it features a specified complexity and is designed; if not, it is caused by chance. A specified event, for Dembski, is an event that conforms to a pattern that can be constructed independently of the event, although not necessarily before the event has occurred. ${ }^{34}$ In other words, if an event is both highly improbable (complex) and definable through a separate pattern without reference to the actual event (specified), it can be inferred as designed.

As for probabilities, Dembski calls the probability of $10^{-150}$ the universal probability bound. This bound is based on three facts: the number of elementary particles in the universe, the maximum rate at which transitions in physical states can occur, and the age of the universe. Dembski deduces that because every specified event requires at least one elementary particle to specify it, and because

33 W.A. Dembski, The Design Inference - Eliminating Chance through Small Possibilities, op. cit., 38-39.

34 Ibid., 136. 
such specifications cannot be generated faster than Planck time, the number of specified events through the history of the universe must fall below $10^{-150}$. Thus, Dembski deduces that every specified event whose probability is less than the universal probability bound is highly improbable to have come about by natural causes. ${ }^{35}$

\section{FROM DESIGN TO A DESIGNER}

To repeat, according to the advocates of ID by using the criterion of specified complexity it is possible to discern between designed and non-designed things in a much more reliable manner than through the traditional design argument. Furthermore, they hold that a design can be - and has in fact been - detected also in the biological world. As Dembski emphasises, "the focus of the intelligent design movement is in biology. That's where the action is." 36 Clearly, if signs of a design were probably discovered in nature, the consequences would be significant. The existence of a supernatural intelligent designer who has designed the objects portraying a specified complexity would be proven with a very high probability. In this sense, this new and more rigorous design argument is, if successful (for now, let us assume that it is), much more effective than the traditional one and a big leap forward in the history of the arguments for the existence of a supernatural being.

In practice, this would mean that naturalistic theories would lose much - if not all - of their credibility in philosophy. At the same time, if the existence of a supernatural being were confirmed, it would obviously open up plenty of chances to develop theistic (or other religious-based) theories of philosophy in a much more solid

35 Ibid., The Design Revolution - Answering the Toughest Questions about Intelligent Design, InterVarsity, Downers Grove 2004, 84-85. For a more thorough treatment, see ibid., Specification - The Pattern That Signifies Intelligence, Philosophia Christi 7(2005)2, 299-343.

36 Ibid., Intelligent Design - The Bridge Between Science and Theology, op. cit., 14. 
manner than is currently possible. In my view, this is exactly the aim of the advocates of an intelligent design - to make explanations appealing to the supernatural acceptable and question the plausibility of naturalistic philosophy.

However, there are limits to the ID's design argument. At best, it is an argument for the existence of some kind of supernatural being. The identity of the supernatural designer would remain a mystery, since the ID theory itself does not have the means to reveal the identity of the designer. Dembski himself admits that: "[T]he designer is compatible with the Creator-God of the world's major monotheistic religions like Judaism, Christianity and Islam. But the designer is compatible with the watchmaker-God of the deists, the demiurge of Plato's Timaeus and the divine reason (i.e., logos spermatikos) of the Ancient stoics. One can even take an agnostic view about the designer, treating specified complexity as a brute unexplainable fact."

Indeed, when discussing the identity of the supernatural designer in the context of ID, it should be kept in mind that the term "supernatural" is understood to refer to any intelligent agent powerful enough to manipulate the development of biological organisms. It is precisely in this regard that the designer would be "above nature", that is, supernatural. Dembski himself thinks that "such an intelligence would in all likelihood be unembodied", but he is also quick to admit that "strictly speaking this is not required of intelligent design - the designer could in principle be an embodied intelligence, as with the panspermia theories." 37

Nevertheless, it must be noted that most of the advocates of ID think that the supernatural designer is the Christian God. This becomes clear in their more popular writings. Dembski, for

37 Ibid., No Free Lunch - Why Specified Complexity Cannot Be Purchased without Intelligence, op. cit., 333. 
example, makes it clear that he believes the designer to be the God of Christianity. ${ }^{38}$

In this sense, the ID's design argument is more agnostic than the classical analogical argument. Whereas William Paley and his fellow Englishmen rather straightforwardly identified the designer as the God of Christianity, advocates of the ID theory stress that such a conclusion cannot be drawn merely on the grounds of the theory. The designer is just some designer. In other words, Hume's criticism regarding the identity of the designer is addressed by dodging the question. On the other hand, from the perspective of Christian apologetics this rather straightforwardly means that Hume's criticism of multiple, infant, or superannuated designers cannot be escaped.

However, it is not clear that even Christians should straightforwardly identify the designer as the Christian God. In fact, it seems that the ID's designer lacks several properties traditionally associated with God, for instance properties concerning omnipotence and transcendence, as I have argued elsewhere. ${ }^{39}$

\section{PROBLEMS WITH THE ID'S DESIGN ARGUMENT}

The ID's design argument also faces other, and more serious, challenges, especially when applied to biology..$^{40}$ By far the most used

38 D. Williams, Friday Five: William A. Dembski, CitizenLink, December 14 2007; W.A. Dembski, Intelligent Design - The Bridge Between Science and Theology, op. cit., 210.

39 J. Loikkanen, William A. Dembski's Project of Intelligent Design, Studia Theologica - Nordic Journal of Theology 72(2018)1, 68-83.

40 I only offer a very short overview of the critique ID has attracted here. For a more detailed analysis, see, e.g.: B. Fitelson, C. Stephens, E. Sober, How Not to Detect Design - Critical Notice: William A. Dembski, 'The Design Inference', Philosophy of Science 66(1999)3, 472-488; H.J. Van Till, 'Intelligent Design' Theory, Two Viewpoints - Does 'Intelligent Design' Have a Chance?, Zygon: Journal of Religion and Science 34(1999)4, 667-675; M. Perakh, Unintelligent Design, Prometheus, Amherst 2003; Why Intelligent Design Fails - A Scientific Critique of the New Creationism, ed. M. Young, T. Edis, Rutgers University Press, New Brunswick 2004; G. Dawes, What is Wrong with Intelligent Design?, International 
example of a biological organism that is allegedly designed (and actually the only one that, for example, Dembski honestly seems to support) is the flagellum of the Escherichia coli bacterium. ${ }^{41}$ Surely, one plausible counterexample is sufficient to disprove the claim that all biological organisms have been produced by natural causes. In other words, if it could be confirmed that the bacterial flagellum exhibits specified complexity - and if it is assumed that the criterion of specified complexity is a reliable method of detecting design in the first place - it must be accepted that supernatural causes have played a part in the development of some biological structures (the flagellum, in particular).

Focusing on this one example does not mean that Dembski thinks there are no other biological objects that are designed. When Dembski suggests that the promoters of intelligent design do not need to be "committed to every biological structure being designed" 42 but merely to "find some clear instances of design and nail them down,"43 this does not appear to fully reflect his personal views. Instead, it seems a strategic choice to only highlight "some clear instances of design." In order to make a case against naturalism, it is not necessary to show that design exists everywhere in the world (although Dembski

Journal for Philosophy of Religion 61(2007)2, 69-81; D. Bartholomew, God, Chance and Purpose - Can God Have It Both Ways?, Cambridge University Press, Cambridge 2008; M. Boudry, S. Blancke, J. Braeckman, Irreducible Incoherence and Intelligent Design A Look into the Conceptual Toolbox of a Pseudoscience, The Quarterly Review of Biology 85(2010)4, 473-482; M.J. Murray, Natural Providence (Or Design Trouble), in: Philosophy of Religion - An Anthology, ed. L.P. Pojman, M.R. Rea, Wadsworth, Belmont 2012, 596612; J. Loikkanen, William A. Dembski's Argument for Detecting Design through Specified Complexity, Philosophy and Theology 27(2015)2, 289-306. See also note 47.

41 W.A. Dembski, No Free Lunch - Why Specified Complexity Cannot Be Purchased without Intelligence, op. cit., 267-302.

42 Ibid., The Design Revolution - Answering the Toughest Questions about Intelligent Design, op. cit., 63.

43 Ibid., The Logical Underpinnings of Intelligent Design, in: Debating Design - From Darwin to DNA, ed. W.A. Dembski, M. Ruse, Cambridge University Press, Cambridge 2004, 311$-330,210$. 
might believe that it does ${ }^{44}$ ). It is enough to highlight one credible example of design.

Dembski sees the flagellum expressing specified complexity and, thus, design. However, following his fellow ID advocate Michael Behe's idea of "irreducible complexity", ${ }^{5}$ he calculates the probability of the formation of the bacterial flagellum through a random assembly of proteins ${ }^{46}$ The theory of evolution, however, suggests that proteins are not drawn together randomly, but evolve in interaction with other molecules from simple forms and gradually form more and more complex structures. ${ }^{47}$ It has been shown that in the case of the bacterial flagellum, there are also plausible scenarios for the structure having evolved gradually without a non-functional intermediate,

44 Dembski believes that "God created nature as well as any laws by which nature operates. Not only has God has created the world, but God upholds the world moment by moment." (W.A. Dembski, Reinstating Design within Science, in: Unapologetic Apologetics - Meeting the Challenges of Theological Studies, ed. W.A. Dembski, J.W. Richards, InterVarsity, Downers Grove 2001, 239-257, 222.)

45 An irreducibly complex system, according to Behe's definition (1996, 39), is "a single system composed of several well-matched, interacting parts that contribute to the basic function, wherein the removal of any one of the parts causes the system to effectively cease functioning." Because the irreducible core of an irreducibly complex system can't be simplified without destroying the basic function, Dembski argues that there can be no evolutionary precursors with simpler cores that perform the same function. It follows that the only way for a direct Darwinian pathway to evolve an irreducibly complex system is to evolve it all at once and thus by some vastly improbable or fortuitous event. In other words, Dembski holds that irreducibly complex systems are necessarily formed in one go because the probability that any putative precursors of an irreducibly complex system could have evolved into a system through evolutionary means is extremely small. W.A. Dembski, Irreducible Complexity Revisited, Progress in Complexity, Information, and Design (2004)3.1.4, 1-47.

46 For exact calculations, see Ibid., No Free Lunch - Why Specified Complexity Cannot Be Purchased without Intelligence, op. cit., 289-302.

47 B. Alberts, A. Johnson, J. Lewis, D. Morgan, M. Raff, K. Roberts, P. Walter, Molecular Biology of the Cell (Sixth Edition), Garland Science - Taylor and Francis, New York 2015, 109-172. 
with selective benefits at each step. ${ }^{48}$ Therefore, it is reasonable to assume that the ordinary evolutionary mechanisms apply in the case of the flagellum.

The ID's design argument suffers from vulnerabilities at a more abstract level as well. The two main problems here concern the universal probability bound and specifications. The universal probability bound was based on the maximum number of possible interactions of elementary particles occurred during the history of the observable universe. However, the probability of an individual event only depends on the characteristics of the phenomenon under investigation, not on the number of all possible events in the universe. Even though there were only $10^{150}$ possible events, some of these events could have a probability lower than $10^{-150}$, and some of them higher than that. There is a difference to be made between counting the number of possible states and assigning a probability distribution over those states. In most real-life cases, using a uniform probability distribution does not make sense. ${ }^{49}$

A specified event was defined as an event that conforms to a pattern that can be determined independently of the event. However, human observers with limited background information may not be able to discern reliably between specified and non-specified events. Their abilities are always conditioned by their knowledge of the event in question. In many real-life situations, where complex patterns cannot be defined with mathematical precision, drawing a clear line between a specification and a non-specification is extremely difficult, unless it has been decided in advance which patterns count

48 M.J. Pallen, N.J. Matzke, From the Origin of Species to the Origin of Bacterial Flagella, Nature Reviews Microbiology 4(2006)10, 784-790; T. Wong, A. Amidi, A. Dodds, S. Siddiqi, J. Wang, T. Yep, D.G. Tamang, M.H. Saier Jr., Evolution of the Bacterial Flagellum, Microbe 2(2007)7, 335-340; B. Chaban, I. Coleman, M. Beeby, Evolution of Higher Torque in Campylobacter-type Bacterial Flagellar Motors, Scientific Reports 8(2018)1, article 97.

49 B. Fitelson, C. Stephens, E. Sober, How Not to Detect Design - Critical Notice: William A. Dembski, 'The Design Inference', op. cit., 485-486. 
as specifications and which do not - and this would be tautological. Hence, there seems to be no way to escape subjectivity and control it adequately. ${ }^{50}$

\section{CONCLUSION}

In its subjectivity relating to specifications, the contemporary version of the design argument comes surprisingly close to the classical one, which was more or less based on an individual observer's intuition whether a particular object show signs of a design. The new argument only frames this in a more technical manner. Of course, subjective impressions are, to varying degrees, present in all human cognitive endeavours. ${ }^{51} \mathrm{~A}$ particular method of detecting design does not have to be completely infallible in order to be useful. However, the ID argument, which is based on a clear distinction between design and non-design and between specified and non-specified objects, precision is called for. ${ }^{52}$ It seems that Dembski and his colleagues have not quite managed to reach the level of rigor they have aimed for.

To extend the analysis to a more general level, it could be argued that real-life events and objects are usually inferred as designed without constructing exact patterns to match them or assigning exact probabilities to their occurrence. Instead, it might be that some phenomena simply correlate with the minds of human observers in a way that convinces them of the presence of a design. Del Ratzsch explains this as follows: "Under certain circumstances, something clicks into place between the shape of our cognition and the focus

50 D. Bartholomew, God, Chance and Purpose - Can God Have It Both Ways?, op. cit., 97-115; M.J. Murray, Natural Providence (Or Design Trouble), op. cit., 600.

51 D.H. Mulder, Objectivity, in: Internet Encyclopedia of Philosophy, ed. J. Fieser, B. Dowden, 2004, (https://iep.utm.edu/objectiv/), [accessed 09/2020].

52 Dembski formulates his theory with the assumption that the pattern "precisely identifies" the event. W.A. Dembski, Specification - The Pattern That Signifies Intelligence, op. cit., 16. 
of our experience. Something fits." An observer's mind recognises a "counterflow," that is, "things running contrary to what, in the relevant sense, would (or might) have resulted or occurred had nature operated freely." 53 This perception of a counterflow can be based, for instance, on "complex structures, coordination of components, adjustment of means to end, interlocking functions, extreme improbability, purposelike behaviors. ${ }^{54}$ This is not very far from the original, more intuitive design argument introduced by Paley and his contemporaries.

To conclude, in my view the big difference between the traditional design argument and the new one is that, if specified complexity was a reliable method to detect design, if the method could be applied to natural phenomena, and if some of these phenomena exhibited specified complexity, then it would be proven with a very high probability that a supernatural designer exists. Inferring objects as designed would not be based on mere intuition anymore. The proponents of ID, and William Dembski in particular, deserve acknowledgement for their attempt to construct an elaborate method for detecting design. Unfortunately, in its current form the argument does not contribute very much to the discussion.

Nevertheless, philosophically speaking the basic question raised by ID is worthy of consideration: "Is nature complete in the sense of possessing all the resources needed to bring about the informationrich biological structures we see around us, or does nature also require some contribution of design to bring about those structures?" 55 This question has intrigued philosophers and theologians, as well as common people, for centuries and it continues to do so today. The final answer to it remains to be determined.

53 D. Ratzsch, Nature, Design, and Science -The Status of Design in Natural Science, State University of New York Press, Albany 2011, 14.

54 Ibid., 12.

55 W.A. Dembski, The Design Revolution - Answering the Toughest Questions about Intelligent Design, op. cit., 132-133. 


\section{BIBLIOGRAPHY}

Alberts B., Johnson A., Lewis J., Morgan D., Raff M., Roberts K., Walter P., Molecular Biology of the Cell (Sixth Edition), Garland Science - Taylor and Francis, New York 2015.

Barrett J., Exploring the Natural Foundations of Religion, Trends in Cognitive Sciences 4(2000)1, 29-34.

Barrett J., Why Would Anyone Believe in God?, AltaMira, Walnut Creek 2004.

Bartholomew D., God, Chance and Purpose - Can God Have It Both Ways?, Cambridge University Press, Cambridge 2008.

Behe M.J., Darwin's Black Box - The Biochemical Challenge to Evolution, Free Press, New York 1996.

Behe M.J., The Edge of Evolution - The Search for the Limits of Darwinism, Free Press, New York 2007.

Boudry M., Blancke S., Braeckman J., Irreducible Incoherence and Intelligent Design - A Look into the Conceptual Toolbox of a Pseudoscience, The Quarterly Review of Biology 85(2010)4, 473-482.

Chaban B., Coleman I., Beeby M., Evolution of Higher Torque in Campylobacter-type Bacterial Flagellar Motors, Scientific Reports 8(2018)1, article 97.

Darwin C., On the Origin of Species by Means of Natural Selection, or the Preservation of Favoured Races in the Struggle for Life, John Murray, London 1859, (http://darwin-online.org.uk/converted/pdf/1859_Origin_F373.pdf), [accessed 09/2020].

Dawes G., What is Wrong with Intelligent Design?, International Journal for Philosophy of Religion 61(2007)2, 69-81.

Dawkins R., The Blind Watchmaker - Why the Evidence of Evolution Reveals a Universe without Design (Illustrated Edition), W.W. Norton, New York 2015.

Dembski W.A., Intelligent Design - The Bridge Between Science and Theology, InterVarsity, Downers Grove 1999.

Dembski W.A., Irreducible Complexity Revisited, Progress in Complexity, Information, and Design (2004)3.1.4, 1-47.

Dembski W.A., No Free Lunch - Why Specified Complexity Cannot Be Purchased without Intelligence, Rowman and Littlefield, Plymouth 2002.

Dembski W.A., Reinstating Design within Science, in: Unapologetic Apologetics Meeting the Challenges of Theological Studies, ed. W.A. Dembski, J.W. Richards, InterVarsity, Downers Grove 2001, 239-257.

Dembski W.A., Specification - The Pattern That Signifies Intelligence, Philosophia Christi 7(2005)2, 299-343. 
Dembski W.A., The Design Inference - Eliminating Chance through Small Possibilities (Cambridge Studies in Probability, Induction, and Decision Theory), Cambridge University Press, Cambridge 1998.

Dembski W.A., The Design Revolution - Answering the Toughest Questions about Intelligent Design, InterVarsity, Downers Grove 2004.

Dembski W.A., The Logical Underpinnings of Intelligent Design, in: Debating Design - From Darwin to DNA, ed. W.A. Dembski, M. Ruse, Cambridge University Press, Cambridge 2004, 311-330.

Derham W., Physico-theology, or a Demonstration of the Being and Attributes of God from His Works of Creation, W. Innys and J. Richardson, London 1754.

Fitelson B., Stephens C., Sober E, How Not to Detect Design - Critical Notice: William A. Dembski, 'The Design Inference', Philosophy of Science 66(1999)3, 472-488.

Hume D., Dialogues Concerning Natural Religion, Penguin Books, London, 1779. Kant I., The Critique of Pure Reason, trans. from German and eds. P. Guyer, A.W. Wood, Cambridge University Press, Cambridge 1988.

Leech D., Visala A., The Cognitive Science of Religion - A Modified Theist Response, Religious Studies 47(2011)3, 301-316.

Leech D., Visala, A. The Cognitive Science of Religion - Implications for Theism?, Zygon: Journal of Religion and Science 46(2011)1, 47-64.

Loikkanen J., William A. Dembski's Argument for Detecting Design through Specified Complexity, Philosophy and Theology 27(2015)2, 289-306.

Loikkanen J., William A. Dembski's Project of Intelligent Design, Studia Theologica - Nordic Journal of Theology 72(2018)1, 68-83.

McGrath A.E., Darwinism and the Divine - Evolutionary Thought and Natural Theology. Wiley-Blackwell, Oxford 2011.

Meyer S.C., Signature in the Cell - DNA and the Evidence for Intelligent Design, Harper One, New York 2009.

Mulder D.H., Objectivity, in: Internet Encyclopedia of Philosophy, eds. J. Fieser, B. Dowden, 2004, (https://www.iep.utm.edu/objectiv/), [accessed 09/2020].

Murray M.J., Natural Providence (Or Design Trouble), in: Philosophy of Religion - An Anthology (Sixth Edition), eds. L.P. Pojman, M.R. Rea, Wadsworth, Belmont 2012, 596-612.

Paley W., Natural Theology, or Evidence of the Existence and Attributes of the Deity, Collected from the Appearances of Nature, eds. M.D. Eddy, D. Knight, Oxford University Press, Oxford 2006.

Pallen M.J., Matzke N.J., From the Origin of Species to the Origin of Bacterial Flagella, Nature Reviews Microbiology 4(2006)10, 784-790. 
Perakh M., Unintelligent Design, Prometheus, Amherst 2003.

Ratzsch D., Nature, Design, and Science - The Status of Design in Natural Science, State University of New York Press, Albany 2011.

Ray J., The Wisdom of God Manifested in the Works of Creation, R. Harbin, London 1717.

Sedley D., Creationism and Its Critics in Antiquity (Sather Classical Lectures 66), University of California Press, Berkeley - Los Angeles 2007.

Sober E., Philosophy of Biology, Westview, Boulder 1993.

The Center for Science and Culture, What Is the Science Behind Intelligent Design?, 2009, (http://www.discovery.org/a/9761), [accessed 09/2020].

Van Till H.J. 'Intelligent Design' Theory, Two Viewpoints - Does 'Intelligent Design' Have a Chance?, Zygon: Journal of Religion and Science 34(1999)4, 667-675.

Visala A., Naturalism, Theism and the Cognitive Study of Religion - Religion Explained? (Ashgate Science and Religion Series), Ashgate, Farnham 2011.

Wallace A.R., On the Tendency of Varieties to Depart Indefinitely From the Original Type, in: Alfred Russel Wallace Classic Writings, Paper 1, ed. C.H. Smith, Western Kentucky University 2009, (https://digitalcommons. wku.edu/cgi/viewcontent. cgi? article=1002\&context=dlps_fac_arw), [accessed 09/2020].

Williams D., Friday Five: William A. Dembski, CitizenLink, December 14 2007, (http://www.citizenlink.org/content/A000006139.cfm), [accessed 09/2020].

Wong T., Amidi A., Dodds A., Siddiqi S., Wang J., Yep T., Tamang D.G., Saier Jr. M.H., Evolution of the Bacterial Flagellum, Microbe 2(2007)7, 335-340.

Young M., Edis T. (eds.), Why Intelligent Design Fails - A Scientific Critique of the New Creationism, Rutgers University Press, New Brunswick 2004.

Juuso Loikkanen

Itä-Suomen yliopisto, Joensuu, Kuopio

(University of Eastern Finland, Finland)

ORCID: https://orcid.org/0000-0001-5739-6729

juuso.loikkanen@uef.fi

DOI: $10.21697 /$ spch.2020.56.3.03 